\title{
Efektivitas Uji Tidak Merusak Dan Uji Merusak \\ Pada Dinding Bata Beton Hasil Perbaikan Dengan Additive Kimiawi Di Daerah Rawan Rob
}

\author{
Ludfie Hardian P.; Erik Kurniawan; \\ Rr.M.I. RetnoSusilorini dan Budi Santosa \\ e-mail : Onlylupek@gmail.com \\ Program Studi Teknik Sipil, Fakultas Teknik \\ Universitas Katolik Soegijapranata, Semarang
}

\begin{abstract}
This research was conducted by using non-destructive test method and destructive test to investigatethe compressive strength of repaired concrete masonry wall with chemical additive sited at Sriwulan Village which is tidal flooding prone area and PucangGading Village. Non-destructive test using Hammer Test was conducted at age 12 months, 13 months, and 14 months after concrete masonry wall being repaired.It was found that in Sriwulan Village, the highest compressive strength is $49.37 \mathrm{MPa}$ at age 14 month whilethe highest compressive strength value is on the in PucangGading is 50,51 MPa at age 13 month. It was also found that destructive test using Core Drill Test was conducted at age 14 month after the masonry wall have been repaired. The highest compressive strength in Sriwulan village was 58,6 MPa and in PucangGading was 82,63 MPa.
\end{abstract}

Keyword : destructive test, non-destructive testcompressive strength, core drill test, hammer test, concrete masonry walll, chemical additive, tidal flooding

\section{PENDAHULUAN}

Pada jaman sekarang penggunaan beton sudah dapat diaplikasikan ke semua item bangunan bahkan dinding bangunan rumah. Dalam pembangunan rumah sendiri pun harus dapat melihat faktor lingkungan sekitar terutama yang berada didaerah pesisir karena sangat rawan "rob" (banjir air pasang yang masuk ke daratan). Pleh karena itu komposisi bahan bangunan terutama dinding harus diberi bahan tambahan additive kimiawi.

Proses perbaikan tempat tinggal (rumah) harus benar dan akurat karena berhubungan dengan keamanan dan keselamatan manusia. Untuk itu sebelum melakukan perbaikanperlu dilaksanakan beberapa uji terhadap beberapa bagian bangunan terutama pada bagian dinding bangunan.
Pada uji dinding dapat digunakan beberapa jenis uji antara lain yaitu: uji tidak merusak (non destructive test) dan uji merusak (destructive test). Uji tidak merusak dapat dilakukan dengan Hammer Test. Hammer Test merupakan sebuah uji mengetahui kekuatan sebuah bangunan dengan cara menembakkan pada titik yang sudah dipersiapkan untuk uji merusak atau Core Drill Test(Karundeng, Vilty Stilvan, 2015).

Pada era modern ini komposisi dinding mengalami inovasi dengan menambahkan bahan additive kimiawi yang bertujuan meningkatkan kekuatan dinding, meningkatkan sifat tahan lama dinding, dan mengurangi segregasi dan bleeding. Pada perbaikan dinding ini menggunakan bahan tambahan berupa MU-200 produksi dari PT. Cipta Mortar Utama. 
Penelitian ini merupakan bagian dari penelitianpayung "Strategi Adaptasi Masyarakat Pesisir Semarang Dan Demak Untuk Mitigasi Pengurangan Resiko Bencana Banjir Dan Rob Akibat Perubahan Iklim" (Susilorini, dkk., 2017) yang mendapat pendanaan dari INSINAS RPI (2017-2019), Kemenristekdikti, Kontrak No.35/INS/PPK/E/E4/2017.

\section{METODE PENELITIAN}

\subsection{METODE PENGUJIAN}

Secara eksperimental dengan Uji Merusak dan Uji Tidak Merusak.

\subsection{PROSEDUR PELAKSANAAN}

Adapun langkah-langkah yang dilakukan dalam penelitian ini adalah sebagai berikut menurut :

a. Pengumpulan tinjauan pustaka sebagai sumber ilmiah yang meliputi dan mencangkup penelitian untuk pengujian hammertest dan core drill.

b. Pengambilan data hasil nilai kuat tekan dengan hammer test pada kajian penelitian terdahulu umur 28 hari sebagai perbandingan nilai kuat tekan dinding di umur14 bulan.

c. Survey lokasi dinding hasil perbaikan terkena oleh air rob (Desa Sriwulan, Kecamatan Sayung, Kabupaten Demak) dan lokasi dinding hasil perbaikan tidak terkena oleh air rob (Perumnas Jl. Pucang Elok Raya ,Pucang Gading, Kota Semarang).

d. Pengujian kuat tekan dinding dengan Hammer Test pada umur 12, 13, dan 14 bulan di Sayung dan Pucang Gading.

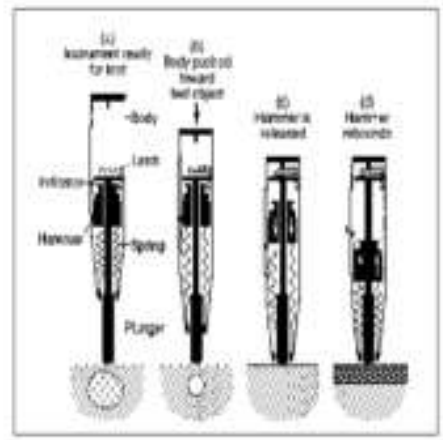

Gambar 1.IlustrasiSkematik Cara

KerjaRebound Hammer( ACI 228. 1R-95)

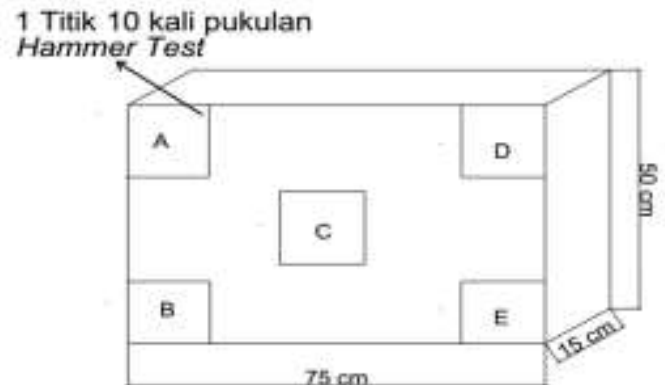

Gambar 2. Perencanaan Hammer Test dengan 5 titik tembakan. 1 titik mendapatkan 10 tembakan

Hammer Test akan dilakukan pada dinding hasil perbaikan dengan 5 titik untuk dilakukan penembakan hammer test dengan jumlah pukulan tiap masingmasing titik sebanyak 10 (sepuluh) kali.

e. Pengujian kuat tekan dinding dengan menggunakan Core Drill pada umur 14 bulan di Sayung dan Pucang Gading.

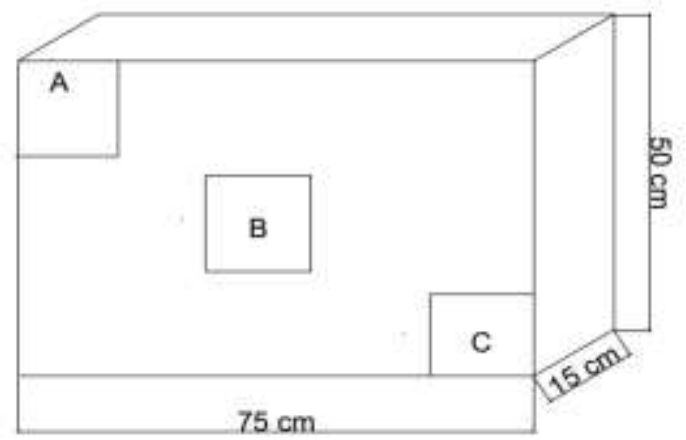

Gambar 3, PerencanaanCore

Drilldengantigatitik pengujian secara diagonal.

Core Drill akan dilakukan pada dinding hasil perbaikan dengan 3 (tiga) titik mewakili 3 (tiga) zona dinding yaitu A, B, dan $\mathrm{C}$.

f. Pembuatan diagram batang hasil perbandingan uji Core Drill pada umur 14 bulan di lokasi Desa Sriwulan dengan Pucang Gading/

g. Kesimpulan hasil data kuat tekanter besar dan terkecil pegujian Hammer Test dan Core Drill.

(Sumber : ACI 228.1R-95) 


\subsection{LANDASAN TEORITIS}

Kuat Tekan Berdasar SNI 03-1974-1990 Kuat tekan adalah besarnya beban per satuan luas yang menyebabkan benda uji beton hancur bila dibebani gaya beban tertentu yang dihasilkan oleh mesin uji kuat tekan .Nilai kuat tekan beton dapat menentukan kinerja dan ketahan beton tersebut sendiri.. Pada pengerjaan Tugas Akhir ini kuat tekan beton dengan rumus sebagai berikut:

$$
\text { 1. } \boldsymbol{\sigma}=\frac{P}{A}
$$

Keterangan:

$\boldsymbol{\sigma}$ : Tegangan normal yaitu kuat tekan beton $\left(\mathrm{N} / \mathrm{mm}^{2}\right)=\mathrm{Mpa}$

P : Beban tekan $(\mathrm{N})$

A : Luas daerah yang tertekan $\left(\mathrm{mm}^{2}\right)$

\subsection{DIAGRAM ALIR}

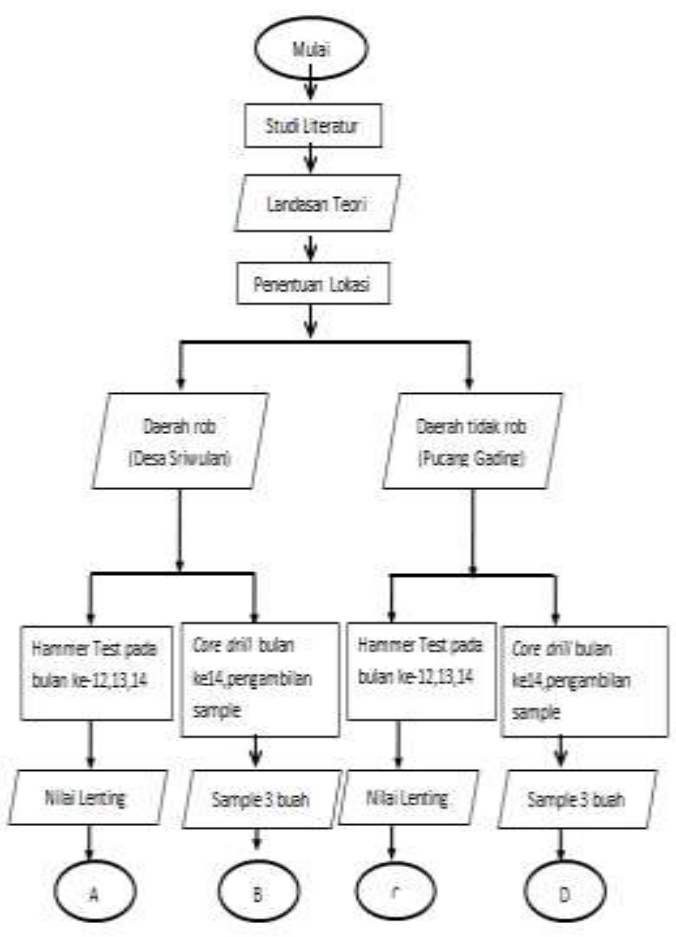

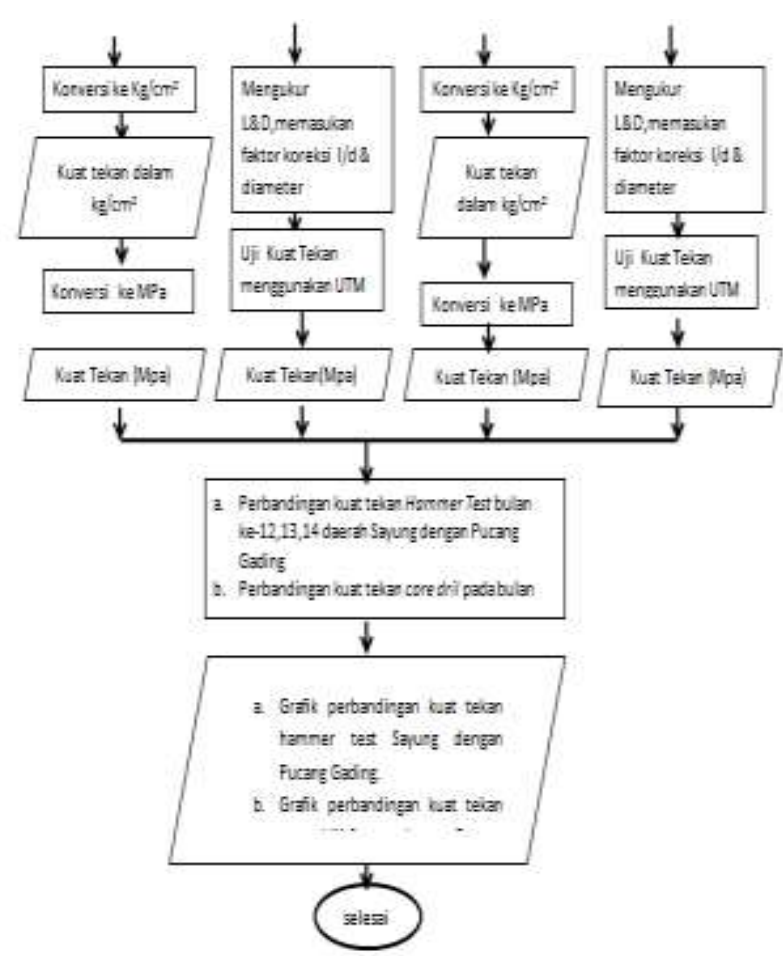

Gambar 4. Diagram Alir Pengujian

\section{HASIL DAN PEMBAHASAN}

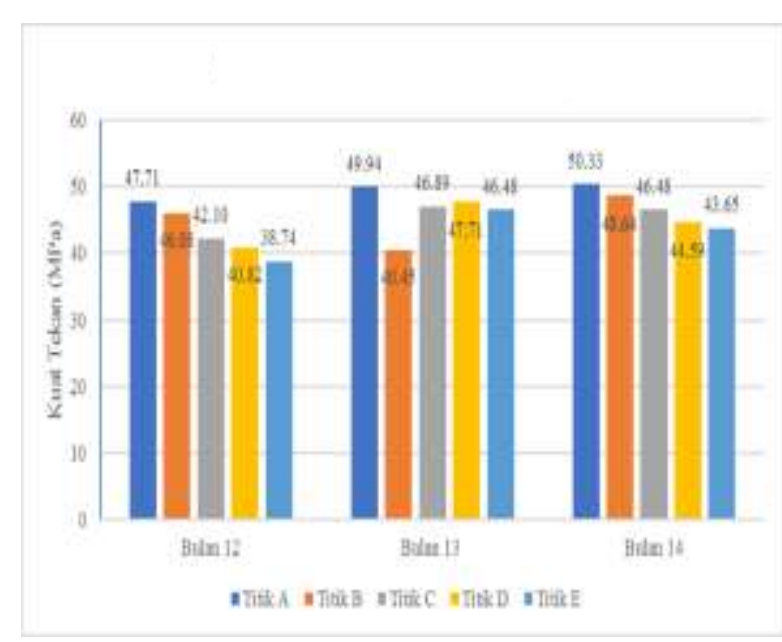

Gambar 5. Perbandingan Rerata Kuat Tekan (MPa) Pengujian Hammer Test Dinding Bata Beton Hasil Perbaikan Pada Umur 12, 13, dan 14 Bulan di Sayung.

Menurut Gambar 5 pada bulan ke-12 kuat tekan tertinggi mencapai $46,8 \mathrm{MPa}$ yang terdapat pada titik $A$, titik A berlokasi di sebelah kiri atas, kemudian titik B mempunyai nilai kuat tekan 45,2 $\mathrm{MPa}$, di titik $\mathrm{C}$ mengalami penurunan ke titik 41,3 $\mathrm{MPa}$, pada tittik $\mathrm{D}$ masih mengalami penurunan dari titik 
sebelumnya dan mempunyai nilai kuat tekan 40,04 Mpa, di titik E yang berada di sebelah kiri bawah mempunyai kuat tekan sebesar $38 \mathrm{MPa}$ dan merupakan nilai terkecil kuat tekan pada bulan ke 12 di lokasi Sayung.

Pada bulan ke-13 nilai kuat tekan titik A mencapai 48,99 $\mathrm{MPa}$, pada titik B yang berada di tengah mengalami penurunan yang cukup signifikan dari titik A yaitu ke 39,68 MPa, di titik C mengalami kenaikan dari titik sebelumnya dan mempunyai kuat tekan sebesar $46 \mathrm{MPa}$, dan pada titik D mengalami penurunan nilai kuat tekan sebesar 0,8 $\mathrm{MPa}$ ke nilai 46,8 $\mathrm{MPa}$, dan titik $\mathrm{E}$ yang berada pada di sebelah kiri bawah mempunyai nilai sebesar 45,6 $\mathrm{MPa}$.

Pada bulan ke-14 nilai kuat tekan tertinggi berada pada titik A dengan nilai kuat tekan 49,37 $\mathrm{MPa}$ sedangkan nilai terendah terjadi pada titik $\mathrm{D}$ dengan nilai kuat tekan 43,74 MPa. Dari hasil kuat tekan di atas dapat disimpulkan bahwa kuat tekan pada bulan ke-13 rata-rata memiliki nilai yang tinggi jika dibandingkan dengan nilai kuat tekan pada bulan ke-12 dan bulan ke-14.

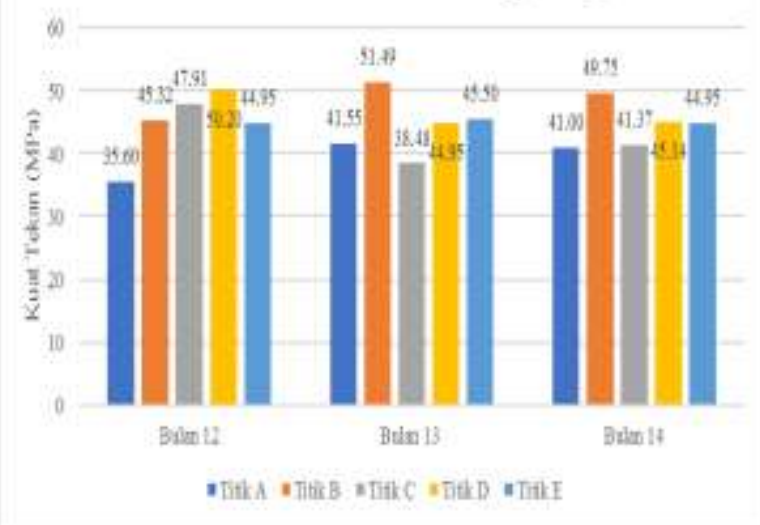

Gambar 6. Perbandingan Rerata Kuat Tekan (MPa) Pengujian Hammer Dinding Bata Beton Hasil Perbaikan Pada Umur 12, 13, dan 14 Bulan di Pucang Gading

Menurut Gambar 6 perbandingan
rerata kuat tekan $(\mathrm{MPa})$

Hammer test dengan campuran additive kimiawi Pada Umur bulan ke- 12, 13, dan 14 bulan di Pucang Gading. Pada umur dinding 12 bulan nilai kuat tekan tertinggi didapatkan pada titik $\mathrm{D}$ dengan nilai kuat tekan 49,25 MPa yang berada di sebelah kanan atas, sedangkan nilai terendah di dapatkan di titik A dengan nilai kuat tekan 34,92 MPa. Sedangkan pada umur bulan ke-13 nilai kuat tekan tertinggi di peroleh oleh titik B dengan nilai kuat tekan sebesar 50,51 MPa dan yang terkecil adalah 37,75 MPa yang berada di titik C. Pada bulan ke 14 nilai tertinggi juga di dapatkan oleh titik B dengan nilai kuat tekan sebesar 48,8 MPa dan yang terkecil di peroleh di titik A dengan nilai kuat tekan 40,22 MPa. Dari hasil kuat tekan diatas dapat disimpulkan bahwa nilai kuat tekan pada titik A setiap bulanya mengalami penurunan hal itu berbanding terbalik dengan titik $D$ yang setiap bulannya mengalami kenaikan nilai kuat tekan.

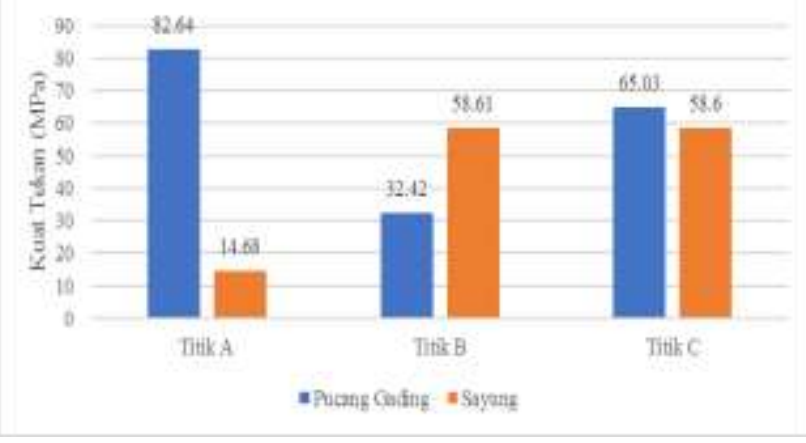

Gambar 7. Perbandingan Rerata Kuat Tekan (MPa) Pengujian Core Drill Dinding Bata Beton Hasil Perbaikan di Daerah Sayung Dengan Pucang Gading

Pada Gambar 7 Nilai tertinggi hasil kuat tekan core drill di peroleh pada titik A di lokasi Pucang Gading dengan nilai 82,64 MPa, sedangkan nilai terendah di perolah olah titik A dengan lokasi pengujian di Sayung. Dari hasil kuat tekan di atas rata-rta hasil kuat tekan benda uji di lokasi Pucang Gading lebih tinggi dari pada hasil kuat tekan sample uji yang 
berlokasi di Sayung ini di sebabkan karena pada lokasi Sayung benda uji setiap hari terkena air rob dan juga berada di lingkungan yang agresif. Pada titik A perbedaan kuat tekan sangat jauh karena sampel titik A di Sayung tercampur dengan bata merah sehingga kuat tekan rendah, sedangkan pada titik B nilai kuat tekan di Pucang Gading lebih rendah karena pada sampel titik B di Pucang Gading terjadi retak yang di akibatkan oleh lubang angkur yang di gunakan untuk melakukan core drill, sedangkan pada titik C nilai kuat tekan Pucang Gading lebih tinggi karena pada daerah Sayung kuat tekan beton juga dipengaruhi oleh lingkungan yang agresif.

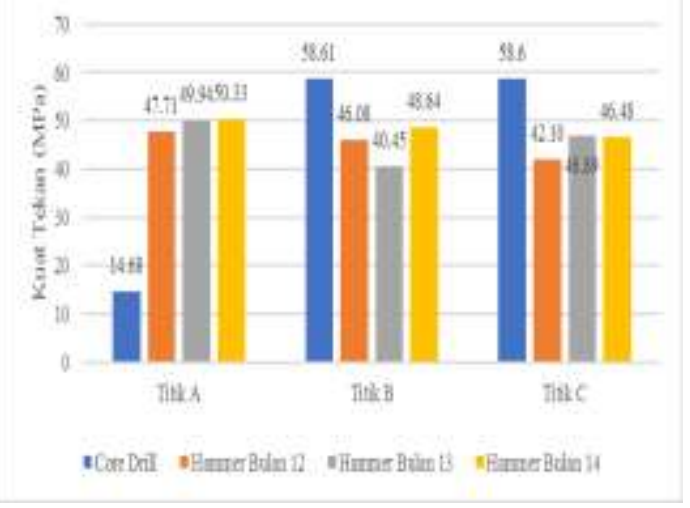

Gambar 8. Perbandingan Rerata Kuat Tekan (MPa) Pengujian Hammer Test dengan Core Drill di Sayung

\section{Sedangkan menurut Gambar 8} Terlihat bahwa pada titik A nilai core drill mempunyai nilai yang sangat kecil yaitu hanya $14,68 \mathrm{MPa}$, dan yang tertinggi di dapat oleh nilai kuat tekan hammer test pada bulan ke-13. Pada titik $B$ nilai tertinggi di peroleh oleh nilai kuat tekan core drill dengan nilai kuat tekan 58,61 MPa dan yang terkecil pada hammer test pada bulan ke-13 yaitu sebesar 39,6 MPa. Dan pada titik $\mathrm{C}$ nilai core drill menjadi nilai kuat tekan yang paling tinggi dengan nilai 58,6 $\mathrm{MPa}$ dan yang paling rendah pada bulan ke-12 yaitu 41,3 MPa. Berdasarkan hasil kuat tekan diatas, nilai core drill sebagian besar mempunyai nilai yang lebih tinggi dari pada nilai kuat tekan hammer test, terlepas dari titik core drill pada titik A yang mempunyai nilai yang sangat rendah Karena sampel yang di ambil tercampur dengan bata merah, sehingga kuat tekan yang dihasilkan menjadi rendah.

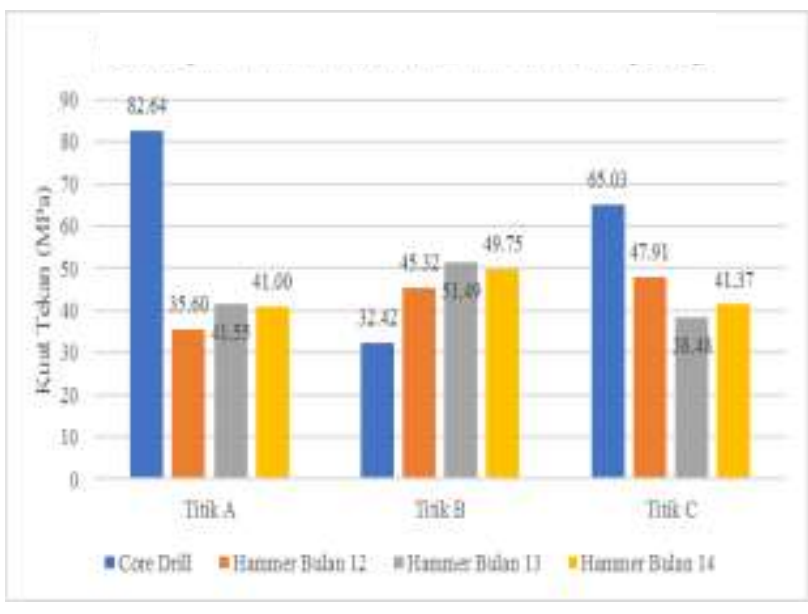

Gambar 9. Perbandingan Rerata Kuat Tekan (MPa) Pengujian Core Drill dengan Hammer Test Pada Daerah Pucang Gading

Menurut Gambar 9 dapat dilihat bahwa pada titik A nilai core drill memperoleh nilai kuat tekan yang sangat tinggi yaitu 82,64 $\mathrm{MPa}$ sedangkan nilai kuat tekan terkecil di dapatkan oleh nilai kuat tekan hammer test pada bulan ke-12 dengan nilai kuat tekan 34,92 MPa. Pada titik B nilai kuat tekan hammer test pada bulan ke-13 memperolah nilai kuat tekan paling tinggi di bandingkan nilai kuat tekan yang lainya dengan nilai kuat tekan sebesar 48,8 $\mathrm{MPa}$, dan nilai terendah di peroleh nilai kuat tekan core drill dengan nilai kuat tekan 32,42 MPa. Pada titik C, nilai kuat tekan core drill mempunyai nilai tertinggi di banding nilai kuat tekan hammer test dengan nilai kuat tekan 65,03 $\mathrm{MPa}$, sedangkan nilai terkecil diperoleh nilai kuat tekan hammer test pada bulan ke-13. Dari hasil perbandingan diatas dapat di simpulkan bahwa nilai kuat tekan core drill secara garis besar memiliki nilai yang lebih besar di bandingkan dengan 
nilai hammer test hal ini di pengaruhi juga oleh bata beton yang digunakan, pada titik B nilai core drill kecil karena titik pengambilan sampel bersebelahan dengan lubang bekas angkur sehingga mengurangi nilai kuat tekan.Pada titik $\mathrm{A}$ dan $\mathrm{C}$ nilai hammer test lebih rendah karena pada pengujian hammer test bagian yang terkena kuat tekan adalah bagian di permukaan sedangkan core drill beton penyusun dinding juga ikut diuji kuat tekan sehingga nilai kuat tekan menjadi lebih tinggi.

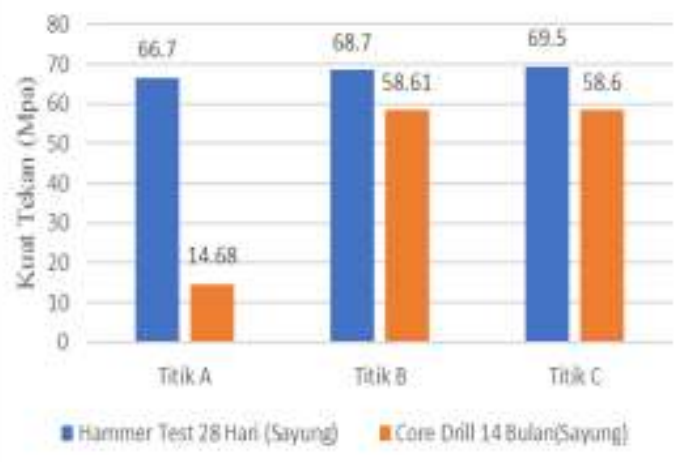

Gambar 10. Perbandingan Kuat Tekan (MPa) Pengujian Core Drill Umur 14 Bulan Dengan Hammer Test Umur 28 Hari

Berdasarkan Gambar 10 hasil data kuat tekan diatas dapat dilihat bahwa nilai kuat tekan tertinggi di dapat oleh mengalami penurunan $15,6 \%$ titik $\mathrm{C}$ pada kuat tekan hammer test pada umur 28 hari dengan nilai kuat tekan 69,5 $\mathrm{MPa}$, sedangkan nilai kuat tekan terendah pada kuat tekan core drill pada titik A mengalami penurunan $73 \%$ dengan nilai kuat tekan 14,68 MPa. Nilai kuat tekan mengalami penuruan $14,6 \%$ dari $68,7 \mathrm{Mpa}$ ke $58 \mathrm{Mpa}$. Dari hasil kuat tekan diatas dapat disimpulkan bahwa nilai kuat tekan beton dengan core drill semua mengalami penurunan dibandingkan dengan nilai kuat tekan hammer test pada umur 28 hari hal ini hal ini karena setelah berada 14 bulan di kondisi yang terkena rob, rongga beton mengalami proses kristalisasi yang di di sebabkan oleh garam di dalam beton sehingga mengakibatkan kehancuran akibat tekanan proses kristalisasi sehingga kuat tekan beton pada umur 14 bulan lebih rendah.

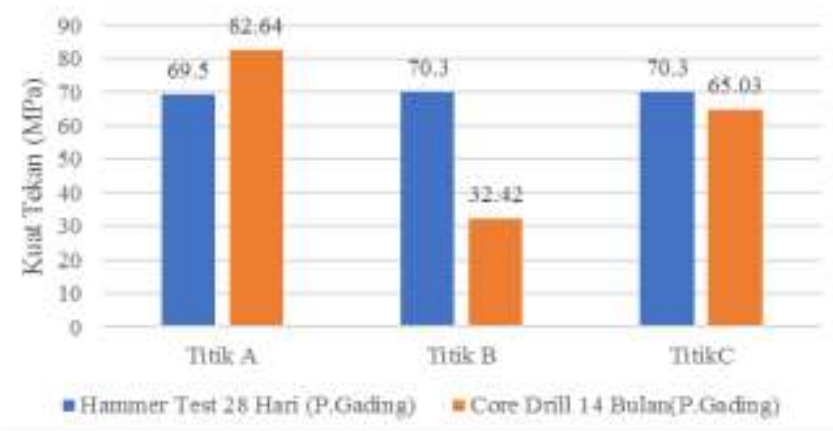

Gambar 11. Perbandingan Kuat Tekan (MPa) Pengujian Core Drill Umur 14 Bulan Dengan Hammer Test Umur 28 Hari

Berdasarkan hasil kuat tekan di atas dapat di lihat bahwa nilai kuat tertinggi pada titik A dengan di nilai kuat tekan 82,64 MPa pada kuat tekan core drill umur 14 bulan mengalami kenaikan 15,9\%, sedangkan yang terendah pada titik B dengan nilai 32,42 mengalami penurunan $53 \%$ pada hasil kuat telan core drill umur 14 bulan. Dapat disimpulkan bahwa nilai kuat tekan hammer test dari titik A ke titik B mengalami kenaikan dan pada titik C nilai kuat tekan tetap stabil dengan penurunan $7,5 \%$, sedangkan untuk nilai kuat tekan core drill mengalami penurunan dari titik A ke B, tetapi mengalami kenaikan kembali pada titik C. Secara garis besar nilai kuat tekan hammer test pada umur 28 hari memiliki nilai kuat tekan yang lebih tinggi karena bata beton yang digunakan mempunyai mutu yang bagus, dan pada titik B titik core drill lebih rendah karena sampel pada titik ini mengalami retak rambut karena efek dari lubang angkur yang di gunakan core rill. 


\section{KESIMPULAN}

Berdasarkan hasil pengamatan dan pengujian kuat tekan yang telah dilakukan pada benda uji Dinding dengan hasil perbaikan dengan additive kimiawi pada daerah Desar Sriwulan Kecamatan Sayung dan Kelurahan Pucang Gading maka didapat beberapa kesimpulan sebagai berikut :

a. Kuat tekan dinding yang diuji dengan metode uji tidak merusak diwakilkan uji Hammer Test pada bulan ke-12 dengan nilai 49,25 Mpa, bulan ke-13 dengan nilai 50,51 Mpa, bulan ke-14 48,8 Mpa untuk daerah Pucang Gading. Untuk daerah Sayung bulan ke12 dengan nilai 46,8 Mpa, bulan ke-13 dengan nilai $48,99 \mathrm{MPa}$, bulan ke-14 dengan nilai 49,37 Mpa.

b. Kuat tekan dinding deng uji core drill daerah Sayung pada titik A dengan nilai 14,68 Mpa, titik B dengan nilai 58,61, titik dengan nilai C 58,6 Mpa. Unutk daerah Pucang Gading titik A dengan nilai 82,63 , titik $\mathrm{B}$ dengan nilai 32,4 Mpa, titik C dengan nilai 65,02 Mpa..

c. Dinding di daerah Sayung mengalami penurunan kekuatan dari hasil perbandingan umur dinding 28 hari dengan umur dinding 14 bulan. Pada titik A mengalami penurunan $73 \%$ dari nilai $66,7 \mathrm{Mpa}$ ke $14,68 \mathrm{MPa}$, Pada titik B mengalami penurunan $14,6 \%$ dari $68,7 \mathrm{Mpa}$ ke 58,6MPa. Pada titik C mengalamipenurunan sebesar $15,6 \%$ mengalami penurunan.69,5 ke 58,6MPa

d. Dinding di daerah Pucang Gading mengalami penurunan kekuatan yang tidak terlalu drastis seperti dinding didaerahSayung dari hasil perbandingan umur dinding 28 hari denganumur dinding 14 bulan. Pada titik A mengalami kenaikan 15,9\%mengalami kenaikan dari 69,5 $\mathrm{MPa}$ ke 82,62MPa. Pada titik B mengalami penurunan sebesar 53\%dari 70,3 Mpa ke 32,42 MPa. Pada titik C mengalami penurunan sebesar 7,5\% dari 70,3Mpa ke 65,03MPa.

e. Keadaan lingkungan sangat berpengaruh pada kekuataan dinding hal ini dapat dibuktikan dari hasil uji yang telah diolah,terutama didaerah Sayung sering mengalami rob .

\section{SARAN}

Setelah melakukan pengujian non destructive dan destructive pada dinding hasil perbaikan dengan additive kimiawi, maka saran yang kami berikan menurut hasil yang telah keluar sebagai berikut :

Pada saat proses perbaikan dinding harus dilakukan dengan rapi dan teliti dalam pengerjaan,dan perawatannya pun juga harus diperhatikan agar memperoleh hasil kuat tekan yang lebih maksimal serta dinding bisa lebih tahan lama

\section{DAFTAR PUSTAKA}

Caresa, Ferista Dea. Mukhamad Sukarno Putro. 2016. Tugas Akhir Perbaikan

Kolom Beton Menggunakan Metode Chipping di Daerah Rawan Rob dengan Bahan Tambah Berbasis Bonding Adhesive. Semarang: Universitas Katolik Soegijapranata.

Desmawan, B. T. (n.d.). Adaptasi Masyarakat Kawasan Pesisir Terhadap Banjir Rob Di Kecamatan Sayung, Kabupaten Demak, Jawa Tengah.

Desmawan, B. T. (n.d.). Adaptasi Masyarakat Kawasan Pesisir Terhadap Banjir Rob Di Kecamatan Sayung, Kabupaten Demak, Jawa Tengah.

Disaptono, S, Budiman, danFirdausAgung 2009. MenyiasatiPerubahanIklim di wilayahpesisirdanpulaupulaukecil.Penerbit PT. SaranaKomunikasiUtama, Bogor. 
Listyawan, T. (2017). Uji Kuat Tekan Core Drill. Semarang: Universitas Diponegoro.

Lubis, Mawardi . 2003. PengujianStrukturBetonDenganMeto de Hammer Test danMetodeUjiPembebanan (Load Test). Medan :Universitas Sumatera Utara

Setiawan, Mohammad Hendri. Silvi Kartikowati. (2016). Tugas Akhir Perbaikan Dinding Dengan Menggunakan Mortar Instan Untuk Daerah Rawan Rob. Semarang: Universitas Katolik Soegijapranata.

Susilorini, Rr.M.I Retno, VG. Sri Rejeki dan Budi Santoso. 2016.Inovasi Beton Bajik untuk Beton Berkelanjutan. Proposal Hibah Kompetensi Tahun ketiga. Direktorat Riset dan Pengabdian Masyarakat : Kemristekdikti

Susilorini, Rr. M.I. R, Suwarno, DJ., Santosa, Budi. 2017. Strategi Adaptasi Masyarakat Pesisir Semarang dan Demak untuk Mitigasi Pengurangan Resiko Bencana Banjir dan Rob Akibat Perubahan Iklim, Semarang, Laporan Akhir, INSINAS RPI, Tahun Pertama, DPTI, Kemenristekdikti.

Acianplesterdanbeton( (diaksespada 31 Oktober 2017, jam 17.39 WIB) 